\title{
Making Better Indonesia's Thin Capitalization Rules (Lesson Learn from China)
}

\author{
Neni Susilawati \\ \{neni.susilawati31@ui.ac.id\} \\ Department of Fiscal Administration, Faculty of Administrative Sciences, Universitas Indonesia, \\ Indonesia
}

\begin{abstract}
Thin capitalization rules are an effective instrument used by the tax authorities in many countries to prevent tax avoidance attempts through base erosion. These rules must be applied while maintaining adherence to the substance over form and the arm's length principles. In Indonesia's case, a stricter thin capitalization rule enables the country to overcome issues of taxation involving multinational corporations as well as issues of base erosion and profit shifting (BEPS). However, in comparison to other countries, the debt-to-equity ratio (DER) applied in Indonesia as part of the country's thin capitalization rule is considered lax. With a tax policy that is non-disincentive to business activities as well as lessons learnt from the regulations prevailing in China in mind, a number of suggestions for a more effective thin capitalization rule in Indonesia are offered, including DER review, application of the arm's length principle as an alternative, revision of the definition and scope of debt, and regulations improvement by providing clarity on the time basis of interest financing, treatment of the penalty imposed on late debt payment, treatment of interest income not considered as an expense to the borrower, and treatment of interest expense that cannot be carried forward to the subsequent period.
\end{abstract}

Keyword: Thin capitalization, BEPS, debt equity ratio, corporate tax, tax policy

\section{Introduction}

In the field of tax avoidance, thin capitalization refers to covert capital obtained from loan in excess of an arm's length amount. The loan in this thin capitalization context is one in the form of cash or capital from a shareholder or another party who establishes a special relationship with the borrower [1]. Thin capitalization refers to a condition under which a company is financed with more debt than equity (highly leveraged).

Multinational corporations are in many cases structured in this manner when they generate profits under a condition where the lenders are from countries that apply very low rates of tax (on interest income) and the borrowers are situated in countries in which interest expense is deductible for income tax purpose. This structure can be established with the shift of profits to countries with lower income tax rates. The high leverage in multinational corporate financing in Indonesia is now capturing the attention of global countries.

\section{Thin capitalization concept}

\subsection{Thin Capitalization Definition}

Thin capitalization develops in the context of parent company's financing for its subsidiary. Parent companies always prefer the financing scheme in which loans are provided for their subsidiaries, which will pay back the loans with interest. If the country in which a 
subsidiary is established applies a high income tax rate, an attempt will be made by the subsidiary to cut down its income tax by increasing income tax deductible expenses. The interest payable to the lender who is not a resident of the country where the borrower lives is typically deductible from the borrower's taxable income, while, contrarily, dividends are not deductible.
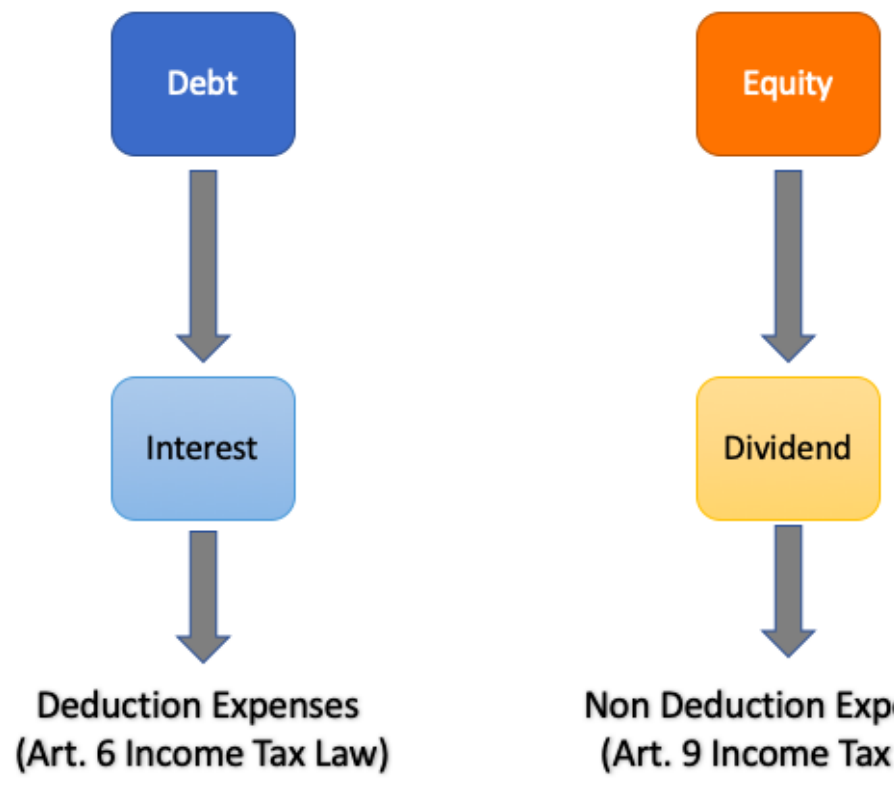

\section{Non Deduction Expenses \\ (Art. 9 Income Tax Law)}

Fig. 1. Implications of Debt and Equity Financing for Income Tax

Figure 1 presents the implications of a parent company's financing for its subsidiary through two different financing scemes. If the parent company conducts equity financing, then it will acquire dividends from its subsidiary as equity income, but according to Article 9 of Income Tax Law, these dividends are not deductible from gross income. But if the financing uses debt or loans for its subsidiary, the parent company will receive loan interest from the subsidiary as a result of that lending. According to Article 6 of Income Law Tax, The interest paid by the subsidiary is deductible from its gross income. For this reason, the debt-based financing sceme is of a greater interest to the parent company as it is capable of alleviating the income tax burden for its subsidiary.

Theoretically, Gunadi [2] defined thin capitalization as the practice of financing a branch or subsidiary with a greater amount of interest-bearing debt than equity. Meanwhile, Rohatgi [1] defined it as covert capital obtained from loan in excess of an arm's length amount. The loan in this thin capitalization context is one in the form of cash or capital from a shareholder or another party who establishes a special relationship with the borrower.

\subsection{Thin Capitalization Scheme Description}

If a subsidiary company decides that the most part of its financing is derived from interest-bearing debt from its parent company, its payable income tax will considerably be 
reduced. Paying interest of withholding tax at a low rate to the parent company will put the subsidiary company at an advantage.

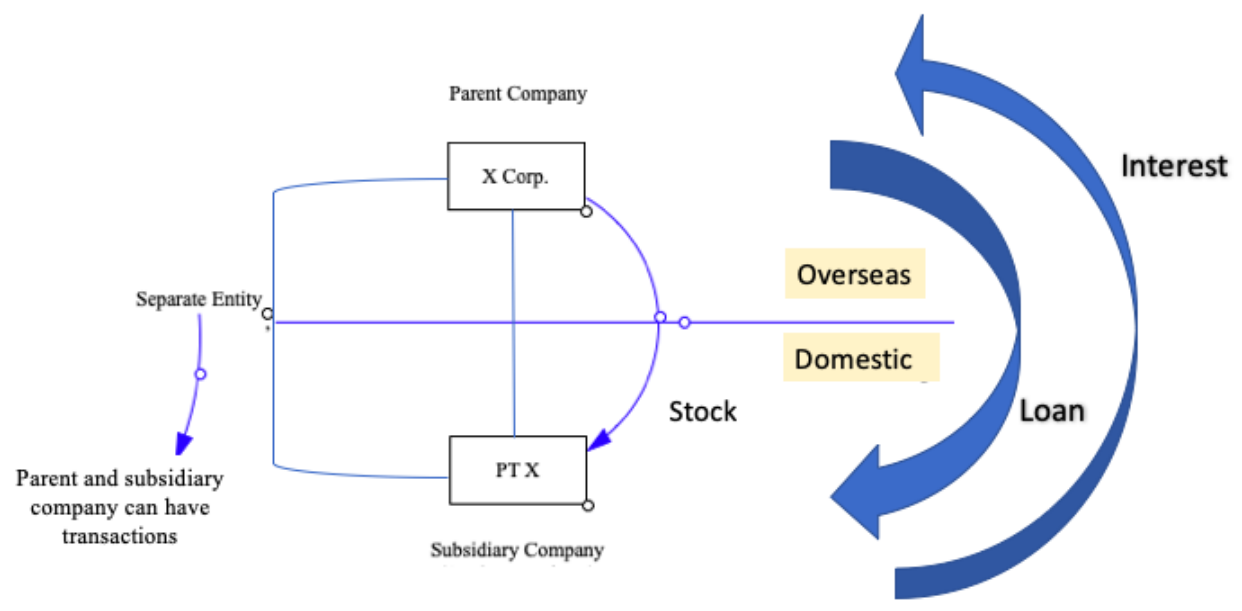

Fig 2. Thin Capitalization Schemes

Thin capitalization practice comes in three scemes: direct loan, back-to-back loan, and parallel loan. Figure 3 below provides a description for each scheme.

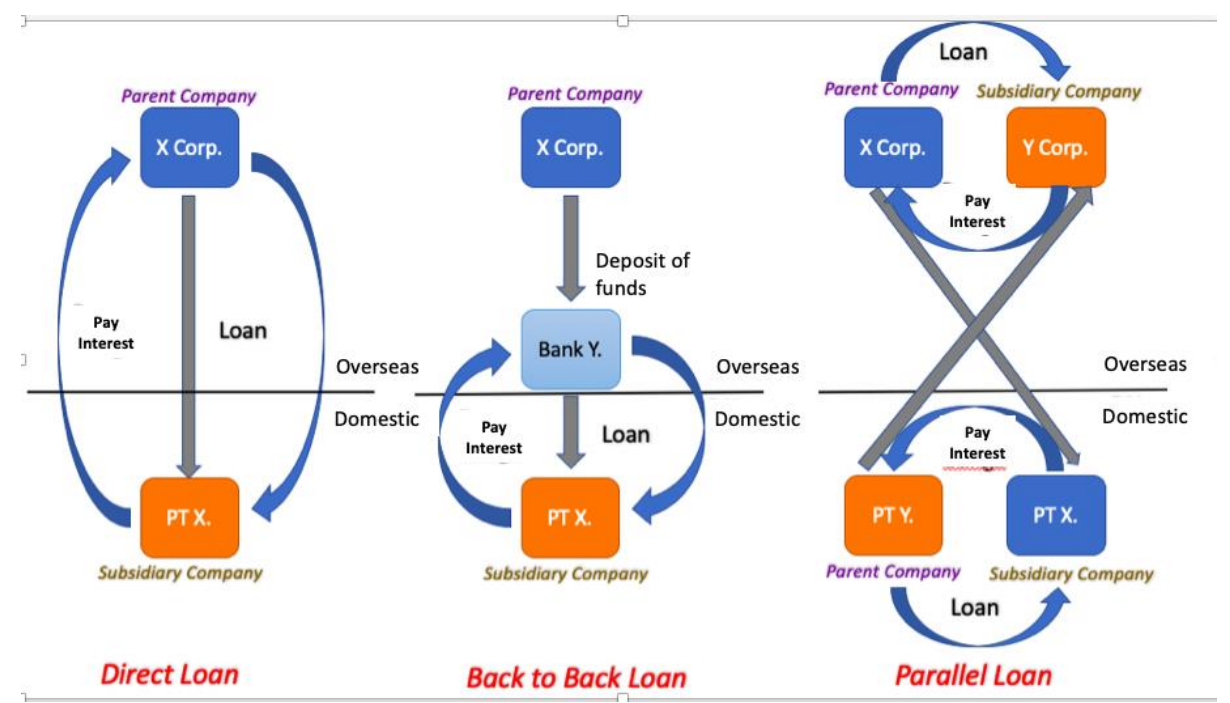

Fig. 3. Thin Capitalization Schemes

In the direct loan scheme, a foreign investor (shareholder) directly provides loans for their subsidiary. They will generate interest income at an amount generally determined on their part. In the back-to-back loan scheme, however, the investor will lend a fund to their subsidiary through a third-party mediator to whom a bonus will be given. Another way of 
implementing this scheme is by depositing a fund to a bank or a financial insitutition, which will provide a loan for the subsidiary company in another country. Meanwhile, in the parallel loan scheme, an investor will seek to establish an agreement with a company in another country, say Indonesia, which has a subsidiary in its country. As a return for the loan given to the Indonesian company's subsidiary in its country, the investor will ask the Indonesian company to also provide its subsidiary in Indonesia with a loan.

\subsection{Thin capitalization simulation for tax efficiency}

All tax avoidance practices, including thin capitalization, are aimed at achieving tax efficiency. The table below presents the difference in the tax burden between when the financing is conducted through the debt scheme and when the equity financing scheme is applied. For the same profit amount, say 100, the tax burden in the debt financing scheme amounts to 20 , but the tax burden in the equity financing scheme is 36.25 . There is a tax saving of 16.25 or $45 \%$. This percentage is certainly a significant amount for the subsidiary.

Table 1. Simulation of Tax Burden Comparison between Debt and Equity Financing Schemes

\begin{tabular}{|c|c|c|}
\hline \multicolumn{3}{|c|}{$\begin{array}{l}\text { How Thin Capitalization Works } \\
\text { Tax Saving from Equity and Debt Financing }\end{array}$} \\
\hline Financing & Equity & Debt \\
\hline Net Profits & 100 & 100 \\
\hline Deduction of Interest & 0 & 100 \\
\hline Taxable Profits & 100 & 0 \\
\hline Corporate Income Tax (25\%) & 25 & 0 \\
\hline Dividend Distribution & 75 & 0 \\
\hline Withholding Tax on Dividends (15\%) & 11,25 & 0 \\
\hline Withholding Tax on Interest (Non treaty, 20\%) & 0 & 20 \\
\hline Total Tax Burden & 36,25 & 20 \\
\hline Tax Saving & 16,25 & \\
\hline Tax Saving Percentage & $45 \%$ & \\
\hline
\end{tabular}

No special, binding provision has been made for guiding any country to deal with tax avoidance in the form of thin capitalization. However, a ratio of debt to equity, also known as DER, is a norm in the international taxation practice to deal with thin capitalization, with a debt-to-ratio of 3:1 being popular among many countries. Other than DER, the arm's length principle can also be used. This principle allows taxpayers flexibility to prove that their transactions are made at arm's length, but the provisions for its application vary for every country. 
Table 2. Comparison of the Effects of Capital Structure on Tax Income

\section{Impact of capital structure on taxable profits - Comparison}

Following example brings to light the impact that a capital structure has on taxable profits:

\begin{tabular}{|c|c|c|c|c|c|c|}
\hline \multirow{2}{*}{ S. No. } & \multirow{2}{*}{ Description } & \multicolumn{3}{|c|}{ Debt-equity Ratio } & \multirow[b]{2}{*}{$\begin{array}{l}\text { Full } \\
\text { equity }\end{array}$} & \multirow[b]{2}{*}{ Full debt } \\
\hline & & $1: 1$ & $2: 1$ & $3: 2$ & & \\
\hline 1 & Equity & 150 & 100 & 120 & 300 & - \\
\hline 2 & Debt @ 10\% & 150 & 200 & 180 & - & 300 \\
\hline 3 & Total Capital (1+2) & 300 & 300 & 300 & 300 & 300 \\
\hline 4 & $\begin{array}{l}\text { Earnings before } \\
\text { interest and tax (EBIT) }\end{array}$ & 50 & 50 & 50 & 50 & 50 \\
\hline 5 & (-) Interest [(2) x 10\%] & 15 & 20 & 18 & - & 30 \\
\hline 6 & $\begin{array}{l}\text { Earnings before Tax } \\
\text { (EBT) (4-5) }\end{array}$ & 35 & 30 & 32 & 50 & 20 \\
\hline 7 & (-) Tax @ 30\% & 10.50 & 9 & 9.60 & 15 & 6 \\
\hline 8 & $\begin{array}{l}\text { Earnings after Tax } \\
\text { (EAT) (6-7) }\end{array}$ & 24.50 & 21 & 22.40 & 35 & 14 \\
\hline 9 & $\begin{array}{l}\text { (-) Dividend } \\
\text { Distribution Tax (DDT) } \\
\text { @ 15\% [(8) x 15\%] }\end{array}$ & 3.68 & 3.15 & 3.36 & 5.25 & - \\
\hline 10 & $\begin{array}{l}\text { Dividend Distributed } \\
\text { (Net) (8-9) }\end{array}$ & 20.82 & 17.85 & 19.04 & 29.75 & - \\
\hline 11 & Total Tax paid $(7+9)$ & 14.18 & 12.15 & 12.96 & 20.25 & 6 \\
\hline
\end{tabular}

The table above simulates the difference in tax burden when the thin capitalization rule applying DER is applied and when it is not, in which case company is financed in two ways: fully with debt and fully with equity. Tax burden is at the maximum when the company is finananced fully with equity, and at the minimum when financing is fully derived from debt with the loan interest expenses being fully charged. As for the case in which DER is implemented, the tighter the DER, the higher the tax burden. On the contrary, the more lenient the DER, the lower the tax burden.

\subsection{Thin Capitalization Rule}

There are two approaches to overcoming thin capitalization: loan limitation approach and interest limitation approach. The two approaches are described in detail below.

a. Loan limitation

1. Arm's length approach. The maximum allowable amount of debt must be determined based on the analysis of arm's length principle implementation by looking at how lenders typically set out the terms and conditions under which borrowers may take on a loan. This approach has an advantage in terms of estimation in that it provides the most accurate estimation of debt-to-equity ratio calculated based on the specific situations and conditions in every case. However, this approach requires certain extents of assessment, high levels of resources and expertise, and high degrees of understanding on the auditor part on the characteristics and lending habits of the lenders. 
2. Fixed ratio approach. The maximum allowable amount of debt must be calculated based on the ratio determined by the tax authority or based on a certain accountable basis. This ratio is named Debt-to-Equity Ratio (DER). This approach is better in terms offering certainty, reducing collection and compliance costs, and implementation simplicity. On the weaker side, it is not reflective of the real economic condition of the company, encourages inconsistency of tax treatment for multinational corporations, and lacks accepted international standards concerning the most appropriate ratio.

b. Interest limitation/earnings stripping. The amount of interest deductible from income is determined based on a certain ratio, namely the ratio of interest to EBIT/EBITDA (earnings before interest, tax, depreciation, and amortization). Some of the countries taking this approach are Germany and Italy at EBITDA of $30 \%$.

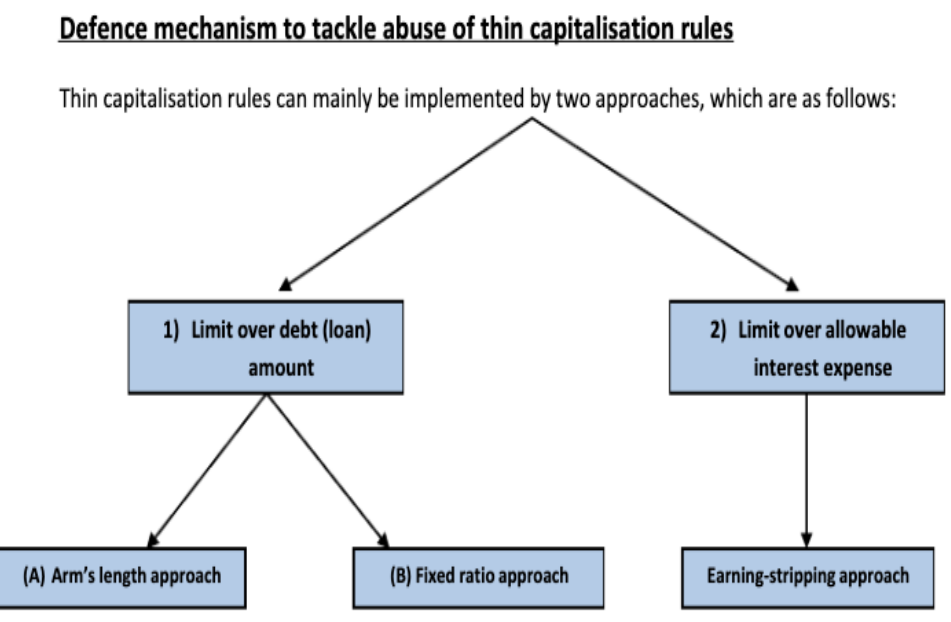

Fig. 4. Approach to Thin Capitalization Rule

Thin capitalization rule implementation may lead to the following consequences:

- classification of debt as equity;

- $\quad$ interest expense cannot be imposed upon subsidiary company; and

- classification of interest payment as distribution of profits upon capital.

\section{Thin capitalization in indonesia}

\subsection{History of thin capitalization rule in indonesia}

The entire history of thin capitalization rule in Indonesia, starting from the time of its first ever establishment to the present, is summed in the figure below. 


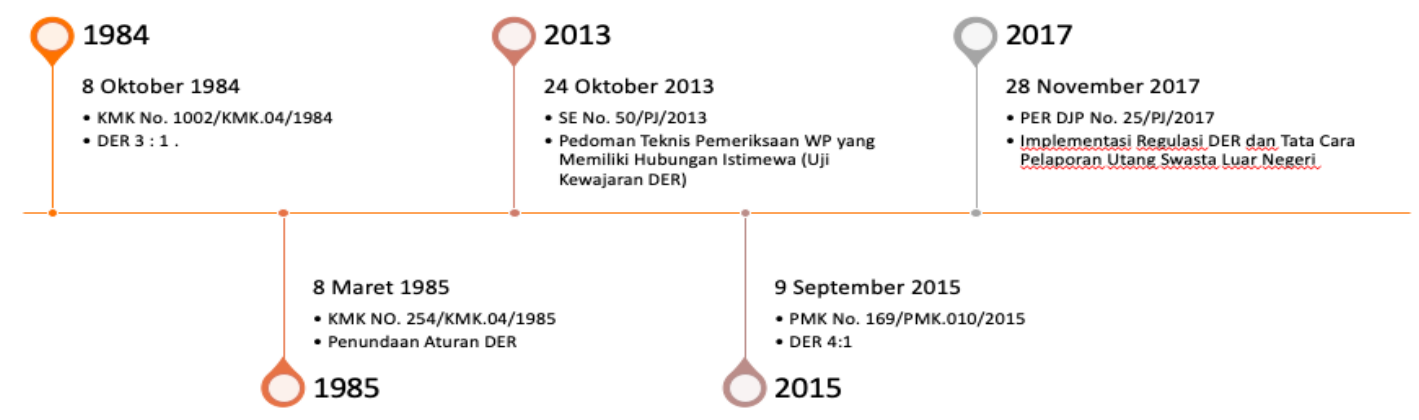

Fig. 5. History of Thin Capitalization Rule in Indonesia Source: Ortax. Processed data

To deal with thin capitalization, on October 8, 1984 the Minister of Finance issued Decision Number 1002/KMK.04/1984 on the Determination of Debt-to-Equity Ratio for Income Tax Calculation Purpose, which set a DER of 3:1 for determining the deductible amount of interest expense for income tax calculation purpose. Six months later on March 8, 1985, the Minister of Finance issued Decision Number 254/KMK.04/1985, which delayed the implementation of the decision above on the basis that the decision could impede investment growth in Indonesia [3].

The Directorate General of Taxes (DJP) then issued a Circular Letter Number SE50/PJ/2013 (SE-50) on October 24, 2013 on the Technical Guide on Audit of Taxpayers with Special Relationships. One of the technical problems covered by SE-50 is intercompany financing, including "the fairness test of taxpayer's DER" as a criterion for analyzing the arm's length basis of the intercompany loan interest rate. However, SE-50 does not provide any explanation on reasonable DER.

After 31 years of delay, the Minister of Finance issued the Regulation of the Minister of Finance Number 169/PMK.010/2015 (PMK-169) on the Determination of Debt-to-Equity Ratio for Income Tax Calculation Purpose on September 9, 2015. With the issuance of PMK169 the previous decision was revoked and a new ratio, 4:1, was enacted. This stipulation is effective since the tax year 2016.

PMK-169 was issued against the backdrop of a sharp increase in the foreign debt taken on by Indonesian companies. According to the most recent data from Bank Indonesia, the country's foreign debt reached USD 304.3 billion by the end of the second quarter of 2015, USD 169.7 billion of which was accounted for by the private sector's debt. Reuters' data revealed that this amount was a 14\% increase from 2014 and was twice the amount in 2010 [4]. PMK-169 provides a detailed guide to the scope of related parties, definitions of debt and equity, DER thresholds, and other compliance requirements.

Despite the detailed guide, some matters regarding the implementation of the regulation are not clearly explained in PMK-169. Thus, the Regulation of the Directorate General of Taxes Number PER-25/PJ/2017 (PER-25) on the Implementation of the Determination of Debt-to-Equity Ratio for Income Tax Calculation Purpose and the Procedure for Private Overseas Debt Reporting was issued on November 28, 2017. PER-25 provides a more explicit explanation on the DER implementation set out in PMK-169. 


\section{2 definitions of debt and equity}

PMK-169 not only sets out the ratio but also the definitions of debt and equity. This regulation defines debt as long-term and short-term debts, including interest-bearing trade payables. The equity definition follows the applicable financial accounting standard and is extended to cover non-interest-bearing debts derived from related parties. In the examples provided in this regulation, the shareholders' equity, share premiums, retained earnings, and non-interest-bearing loans from related parties are all considered to be equity.

The 4:1 DER calculation was based on

a) the average debt and equity balances at the end of each month of the relevant tax year or

b) the average debt and equity balances at the end of each month of part of the subsequent tax year.

This regulation then stresses that for taxpayers with zero or less than zero equity balance, all loan costs will be disallowed for income tax calculation purpose. This provision caution taxpayers with negative retained earnings that this condition might reduce the amount of deductible loan costs.

\subsection{Exceptions}

The 4:1 DER applies to all Indonesian taxpayers established or domiciled in Indonesia except for certain sectors which are guided by special regulations, namely

a) banks;

b) financial institutions;

c) insurance and reinsurance companies;

d) oil and natural gas mining, general mining, and other mining companies bound by production sharing contract, employment contract, or coal mining contract, which specifies the applicable debt-to-equity ratio;

e) companies subject to final income tax; and

f) companies engaged in the infrastructure industry.

\subsection{Impacts on Loan Costs}

If the debt-to-equity ratio of a taxpayer exceeds $4: 1$, the loan costs deductible from the taxable income are limited to only the loan costs deductible for the 4:1 DER. The costs related to the loan that can be calculated are as follows:

a) loan interest;

b) discounts and premiums on loan;

c) additional costs related to borrowing arrangement;

d) finance charges on financial lease;

e) guarantee fees; and

f) the difference in the foreign exchange rate arising from loans in a foreign currency provided that the difference is an adjustment to the interest expense and costs referred to in $\mathrm{b}, \mathrm{c}, \mathrm{d}$, and $\mathrm{e}$.

If a taxpayer takes on an intercompany loan, they must also comply with the arm's length principle as referred to in Article 8 paragraph (3) of Law Number 36 of 2008 on Income Tax. If the taxpayer has zero or negative equity, all of the debt costs will not be deductible from the taxable income.

Every cost of debt in excess of the 4:1 ratio will not be deducted in the income tax calculation. For instance, if a taxpayer applies a 6:1 DER, two-sixths of the loan costs will not 
be deducted in the income tax calculation. It is worth noting that this rule applies to related parties and third parties alike, either overseas or at home. However, it is not explained in PMK-169 whether the non-deductible interest cost can be carried forward to the next year as a deductible expense.

Taxpayers should take into account exchange rate volatility in the case of foreign debt, given that Indonesian Rupiah has been drasticially depreciated over the last two years. If Rupiah constinuously declines from its current level, companies' loans might increase, and in turn, this increase might affect their ratio.

Not only the DER, PMK-169 also specifies that the interest expense of the debt from related parties must adhere to the arm's length principle applicable in Indonesia, which include the requirement for loan needs documentation, presence test, and analysis of the arm's length basis of the interest rate applied.

Taxpayers with private overseas debt are required to not only comply with the DER specified by PMK-169, but also deliver reports on the amount of their debt to the Directorate General of Taxes. Otherwise, a prohibition to relate loan costs to private overseas debt will be imposed. The Directorate General of Taxes has issued a separate implementating regulation as a procedure for foreign private debt reporting, namely the Regulation of the Directorate General of Taxes Number PER-25/PJ/2017 on the Implementation of the Determination of Debt-to-Equity Ratio for Income Tax Calculation Purpose and Procedure for Foreign Private Debt Reporting (PER-25).

\subsection{DER calculation and private overseas debt reporting obligation}

PER-25 provides an explanation of the implementation of thin capitalization rules in Indonesia, including a company's obligation to report DER calculation and private overseas debt details to the Directorate General of Taxes as part of annual income tax return. This DER rule has been in effect since the fiscal year 2016. However, the requirement to attach DER calculation and private overseas debt reports is applicable in the fiscal year 2017 onwards. The DER calculation and private overseas debt reporting must be performed using the form provided in the PER-25 annex. Some key aspects of PER-25 are outlined in the following.

\subsubsection{General Approach}

Consistent with PMK-169, PER-25 applies to the broadly defined loan costs, including interest, premiums, discounts, guarantee fees, other costs incurred for borrowing arrangement, loan financing cost, and the foreign exchange gains and loss related to the loan. Banks, insurers, and other specific industries remain outside of the thin capitalization rules.

Debt and equity balances will be calculated using the average of month-end balances. The term "debt" encompasses short-term and long-term debts as well as interest-bearing trade payables. The term "equity" is defined as the amount indicated in the financial statement but increasing with the non-interest-bearing intercorporate loan. Under the DER regulation, all loan costs exceeding the required 4:1 DER will be permanently prohibited for deduction.

PER-25 provides a number of examples of DER implementation and adjustments for other matters in the regulation, for example, borrowings for non-deductible purpose. PER-25 also clarifies that the deductible interest expense under the DER rule must also be in accordance with the conditions of deductibility in Articles 6 and 9 of Income Tax Law. 


\subsubsection{DER Rule and Arm's Length Principle Implementation}

If a company takes on an intercompany loan from a related party, as an addition to the thin capitalization rules, the interest expense must also satisfy the arm's length principle. The interest expense of the debt in excess of the 4:1 DER will be treated as a dividend for the lender at the time of interest payment or maturity.

\subsubsection{Provisions on the Delivery of Annual DER and Private Overseas Debt Reports}

PER-25 lays down the implementing rules for PMK-169 which require the attachment of DER calculation in a prescribed form to the annual corporate income tax return. In the case of non-attachement of such form, the company will potentially be subject to a penalty as its annual corporate income tax return is deemed incomplete.

The company that takes on a private debt from overseas must also deliver a private overseas debt report using a standard form as an attachement to the annual corporate income tax return. Without the attachement of the form, the annual corporate income tax return will be deemed incomplete, and the overseas debt interest expense will not be deductible.

\subsection{Thin Capitalization Rules Significance for Indonesia}

According to Kristanto, the implications of thin capitalization rules for Indonesia today are as follows:

a) they help tax authority collect tax in a greater amount amid the growing demand for tax revenue;

b) they increase tax burden for taxpayers as in essence, they add more non-deductible costs into the tax liability calculation; in other words, the effective income tax rate is also increased;

c) they assist taxpayers in reviewing their financing arrangement to mitigate the impact of the DER rule; and

d) they suggest that companies that suffer from loss due to negative equity should consider fresh capital injection or debt-to-equity swap; for the time being, converting shareholder loan into interest-free loan for the purpose of satisfying the prescribed DER can be considered as an alternative option.

\section{Thin capitalization according to the oecd and the UN}

DER is the most common thin capitalization rule approach implemented in international countries for its simplicity, for example, with a DER of 3:1. Australia implemented the 3:1 DER, Canada 1.5:1, Japan 3:1, and the U.S. 1.5:1 [5].

However, the OECD argues that DER implementation comes with some disadvantages, such as, the fairly high flexibility in terms of the rate of interest paid by an entity on its debt and the potential of an antity with big capital to deduct more interest expenses. It is also easy for a business group to manipulate the debt-to-equtiy ratio by increasing the equity ratio within a certain entity ("Thin Capitalization Development..").

The UN explains that the earnings stripping approach is more recommended by the OECD as it is able to directly curb base erosion with taxpayers unable to deduct interest expenses past the prescribed threshold, unlike the DER approach which curbs base erosion in an indirect manner. 
It is hoped that Indonesia, a G20 member sponsoring the OECD's BEPS Action Plan, including Action Plan 4 which pertains to thin capitalization, conducts an in-depth review of the implementation of interest limitation/earnings stripping rule in its tax system.

\section{Thin capitalization in china}

On September 19, 2008, the Ministry of Finance and the State Administration of Taxation issued the Notice on Tax Policy concerning the Criteria for Pre-Tax Deduction of Interest Expenses to Related Parties, Cai Shui [6] No. 121 (the "Notice"). The Notice provides a guide to the implementation of the thin capitalization rule introduced by the new Corporate Income Tax Law, which came into effect on January 1, 2008. The author defines the term "Related Parties" here as parties with special relationships.

\subsection{Actual interest payments}

According to the Notice, an entity may deduct the actual interest expenses paid to a related party within the allowable debt-to-equity ratio thresholds. Interest financing must be conducted on an actual payment basis. Accrued but unpaid interest expenses are not deductible. It is unclear how this rule interacts with the withholding tax rule. According to Article 37 of the Corporate Income Tax Law, borrowers are obliged to withhold tax when interest is paid and due or payable to non-resident companies. According to Article 105 of the Implementing Regulation of the Corporate Income Tax Law, "due and payable" refers to the amount of interest that must be paid or accounted for by taxpayers on an accrual basis. For this reason, there is a risk that a borrower needs to withhold and pay the withholding tax on the interest payable to a related party while no tax deduction is allowed.

\subsection{DER}

The Notice prescribes a DER of 5:1 for financial enterprises and 2:1 for other enterprises. The related-party debt includes not only the direct debt from a related party but also back-to-back loan and other investments in debt nature that are indirectly obtained from the related party. The interest on the related-party debt in excess of the allowable amount will not be deducted in the calculation of taxable income for corporate income tax purpose in current year or future periods. However, if sufficient evidence is in place (e.g., file of thin capitalization special edition) to show that the financing arrangement is at arm's length, the interest expenses can be deducted entirely despite exceeding the prescribed ratio (PWC, "Thin Capitalization").

In computing the debt-to-equity ratio, only the debt and equity from related parties is considered, while the debt from unrelated parties is excluded. For instance, if a company with equity of 100 borrows 100 from an unrelated bank and assumes a parent loan of 200, the related-party debt-to-equity ratio is $2: 1$, while the company's debt-to-equity ratio is $3: 1$. In such situation, the thin capitalization rule does not prohibit deduction of interest on the parent loan. It is not clear whether the equity is the amount of registered capital or net equity. Since the thin capitalization concept is based on the notion of the ability to borrow on the market, net equity (that is, the registered capital and capital reserves adjusted for the accumulation of retained earnings or loss) will make sense. 


\subsection{Exceptions}

The Notice provides two exceptions. First, if a company is able to prove that the relatedparty loan meets the arm's length principle, it will be able to deduct the expenses of interest on the related-party loan although the related-party debt-to-equity ratio exceeds the standard. Second, if the actual tax rate of the borrowing company is no higher than that of the relatedparty lender in China, the borrowing company will be able to deduct the actual expenses of interest payment to the related party. These exceptions do not apply to cross-border transactions.

\subsection{Debt-to-Equity Ratio in Relation to "Total Investment-to-Registered Capital" Ratio}

China's foreign investment regulations provide for "total investment-to-registered capital" ratios. "Registered capital" is actual paid-in capital, and "total investment" is registered capital plus debt. Theoretically, debt may cover all company debts. In practice, only foreign debts are considered in the calculation of "total investment-to-registered capital" ratio and applicable in foreign debt registration process. The company must register its foreign debts according to Chinese foreign exchange regulations. A foreign-invested companies cannot register its foreign debts if the accumulated amount of medium- to long-term (more than one year) foreign debts and short-term loan balances (one year or less) exceeds the difference between the company's total investment and registered capital. Without proper registration, a foreign company will not be able to convert the loan proceeds into RMB and send funds for interest and principal payments.

The "total investment-to-registered capital" ratio is tested on an enterprise basis. For foreign debt registration purpose, all foreign debts of foreign-invested companies, including related and unrelated debts, will be considered. Under the thin capitalization rule, only relatedparty debts, including foreign and domestic debts, will be considered. As a result, all debt financing of a company that is fully foreign-owned is derived from its foreign parent company. The foreign-invested company can use as a basis for calculation only a loan amount of less than the "total investment-to-registered capital" ratio under the foreign-investment regulations or the debt-to-ratio under the thin capitalization rule. The table below compares the ratio under foreign-investment regulations to the thin capitalization rule applicable to nonfinancial foreign-invested companies.

Table 3. Comparison of ratio under the foreign-investment regulations and the thin capitalization rule applicable to non-financial foreign-invested companies

\begin{tabular}{lccc}
\hline \multirow{2}{*}{$\begin{array}{c}\text { Registered capital (USD } \\
\text { in millions) }\end{array}$} & \multicolumn{2}{c}{ Foreign-investment regulations } & $\begin{array}{c}\text { Thin capitalization } \\
\text { rule }\end{array}$ \\
\cline { 2 - 3 } & $\begin{array}{c}\text { Total investment to } \\
\text { registered capital }\end{array}$ & $\begin{array}{c}\text { Approximate equivalent } \\
\text { of debt to equity }\end{array}$ & Debt to equity \\
\hline Less than 2.1 & $1.43: 1$ & $0.43: 1$ & $2: 1$ \\
& & & \\
2.1 to less than 5 & $2: 1$ & $1: 1$ & $2: 1$ \\
5 to less than 12 & $2.5: 1$ & $1.5: 1$ & $2: 1$ \\
12 and more & $3: 1$ & $2: 1$ & $2: 1$ \\
30 to less than 100 & & $4: 1$ & $2: 1(?)$ \\
(investment holding co. & & & \\
$\begin{array}{l}\text { only) } \\
100 \text { or more (investment } \\
\text { holding co. only) }\end{array}$ & & $6: 1$ & $2: 1(?)$ \\
\hline
\end{tabular}


A foreign-investment holding company is a special vehicle that can be used by foreign companies to hold their China investments. Foreign-investment regulations allows a higher influence on a foreign-investment holding company than other non-financial companies. The thin capitalization rule does not provide debt-to-equity ratio to the foreign-investment holding company. It seems that the $2: 1$ ratio also applies to the foreign-investment holding company. Given the higher influence permitted by the foreign investment regulations, it would likely be easier for a foreign-investment holding company to take advantage of the exceptions of the arm's length principle to the debt-to-equity ratio.

\subsection{Treatment of interest received}

The thin capitalization rule does not redetermine the interest to be received by relatedparty lenders. If the interest expenses are not deductible to borrowers, the interest will remain treated as interest income to the lenders who are subject to income tax.

\section{Differences of thin capitalization rules in indonesia and china}

Based on the description above, the differences of thin capitalization rules in Indonesia and China are outlined below.

Table 4. Differences of thin capitalization rules in Indonesia and China

\begin{tabular}{|c|c|c|}
\hline Differences & Indonesia & Cina \\
\hline DER & $\begin{array}{l}4: 1 \text { for companies other than } \\
\text { those engaged in special sectors }\end{array}$ & $\begin{array}{l}5: 1 \text { for financial companies } \\
2: 1 \text { for other companies }\end{array}$ \\
\hline
\end{tabular}

For companies engaged in special sectors (e.g., financial sector), no specific ratio is prescribed.

Payment time basis Not explained

- Long-term debts

- Short-term debts

- Interest-bearing payables

Arm's length principle implementation
Aside from passing the DER test, expenses of interest on debt from related parties must also meet the arm's length principle, including the requirement for debt needs documentation, presence test, and analysis of the arm's length basis of the interest rate applied.

In conclusion, after passing the DER test, an entity must also pass the arm's length test to have the interest financing permitted.
Interest financing on actual basis

Debts from related parties include the following:

- direct loans;

- back-to-back loans; and

- other investments in debt nature indirectly obtained from related parties (parallel loans)

If sufficient evidence is in place (e.g., file of thin capitalization special editioin) to show that the financing arrangement is at arm's length, interest expenses can be deducted entirely despite exceeding the prescribed ratio.

In conclusion, arm's length test can serve as an alternative in the event of failure in DER test. 


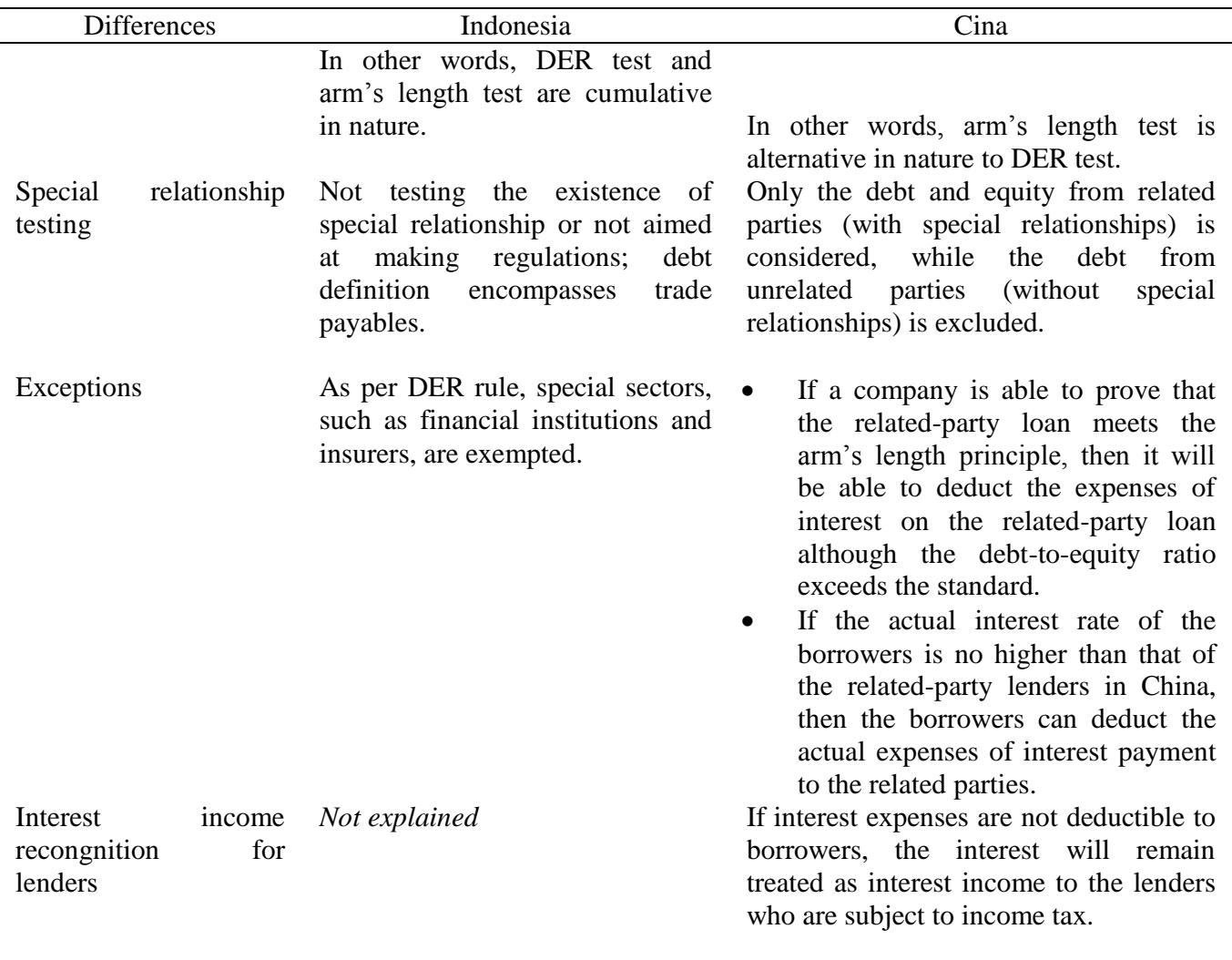

\section{Critical view of thin capitalization in Indonesia}

In comparison to other countries, the DER implementation in Indonesia is stricter. At a glance, the regulations in Indonesia seem to be lax, which is assumed to be aimed to encourage investments into Indonesia. However, when it is scrutinized further, the thin capitalization rule in Indonesia specifies broader definition and coverage of debt, requires entities to go through arm's length test after undertaking DER test, and lacks testing of special relationship. This shows that the thin capitalization rule in Indonesia comes with stricter terms and conditions instead. Despite having lax ratio, stricter terms and conditions will make administration process more complicated. Investors will find the ease to be present only on the surface. This falls short of the ease of administration principle as both taxpayers and the authority are required to perform an in-depth review first before coming to implement the thin capitalization rule.

In light of thin capitalization rules' initial purpose of curbing tax avoidance attempts in the form of base erosion by related parties, it is recommended that the existing definition and scope of debt be reviewed. For the time being, the debt referred to in the existing regulations covers long-term debts, short-term debts, and interest-bearing trade payables. Learning from China, the debt coverage should be readjusted in order to be able to cover the debt between related parties in the form of direct loans, back-to-back loans, and parallel loans. It should also be considered to drop trade payables from the debt coverage because related parties may 
conduct trade transactions using the arm's length principle. In order for the authority to be able to cover the three types of debt, it is necessary for them to improve its database strength, so any scheme in which taxpayers practice thin capitalization can be identified.

The arm's length principle and the DER should be implemented in an alternative rather than cumulative way. This is necessary to avoid distorting taxpayers' business activities which fail to meet the ratio standard but genuainly run at arm's length. Thus, the authority should conceive a standard for special thin capitalization file as is implemented in China.

To add to the author's recommendation in point 2, it is also suggested that the government should define in regulations that the thin capitalization rule is specified for related parties (parties with special relationships), directly or indiriectly.

To meet the principle of legal assurance, it is suggested that a DER ratio be applied to certain sectors, such as financial institutions and insurers, as is applied in China.

After all the briefly-described elements in the thin capitalization rule in Indonesia are improved to be more comprehensive, definitive, and consistent with the philosophy of its establishment, the author recommends that the applicable DER be revised. For general transactions, the DER can be made stricter, while for special sectors, a DER may be defined and described. Strong political will is needed to make this happen. Riciuti, Savoia, and Sen [7] argue that political institutions, seen as the sys- tem of checks and balances on the executive, are a key ingredient for building administrative capacity.

More definitive provisions should be made for the following matters: is the imposition of penalty on late debt payment counted as debt too? can a non-deductible interest expense be carried forward and be deductible in the subsequent year? is the interest expense nondeductible to the borrower still treated as interest income to the lender who is subject to income tax? is the time basis allowed for the interest payment cash basis or accrual basis?

With regard to overseas debt, taxpayers should take into account exchange rate volatility, given the fact that Indonesian Rupiah now has been drastically depreciated over the last two years. If this decline carries on, companies' loans may increase, and in turn, this increase may influence their ratio.

\section{Conclusions}

Thin capitalization rules are an effective weapon used by the tax authorities in many countries to prevent tax avoidance attempts through base erosion. There are two approaches to thin capitalization rule, namely debt limitation and interest limitation. If this rule is implemented rigidly, it might impede the interest of taxpayers who have no slight intention to engage in tax avoidance. This rigid implementation may also be perceived to interefere with taxpayers' businesses. It is clear that this rule must be implemented while still keeping in line with the substance over form and the arm's length principles. In comparison to other countries, the debt-to-equity ratio (DER) applied in Indonesia is deemed to be lax, necessitating a review of the thin capitalization rule applied in Indonesia for the DER as well as other provisions, such as ones regarding the definition and scope of debt.

PMK-169 provides clarity for the Directorate General of Taxes' aim to contain base erosion in Indonesia through the payment of "excessive interest" on debt from related parties. A stricter thin capitalization rule enables the country to overcome issues of taxation involving multinational corporations as well as issues of base erosion and profit shifting (BEPS). This rule also enables the tax authority to generate higher income tax revenues. This goes in line with the Directorate General of Taxes' plan to make the year 2016 a year of Tax Law Enforcement in Indonesia. 
The implementation of this thin capitalization rule will likely to impact both domestic and foreign enterprises in conducting business in Indonesia. It is suggested that taxpayers should carry out a comprehensive review of the arrangement of intercompany financing through robust paperwork for transfer pricing to back up the expense deduction.

With a tax policy that is non-disincentive to business activities as well as lessons learnt from the regulations prevailing in China in mind, a number of suggestions for a more effective thin capitalization rule in Indonesia are offered, including DER review, application of the arm's length principle as an alternative, revision of the definition and scope of debt, and regulations improvement by providing clarity on the time basis of interest financing, treatment of the penalty imposed on late debt payment, treatment of interest income not considered as an expense to the borrower, and treatment of interest expense that cannot be carried forward to the subsequent period.

\section{References}

[1] R. Rohatgi, Basic Internasional Taxation. New York: Kluwer Law Internasional, 2002.

[2] Gunadi, Transfer Pricing: Suatu Tinjauan Akuntansi, Manajemen dan Pajak. Jakarta, 1994.

[3] P. Kristanto, “New Thin Capitalisation Rules," 2016. [Online]. Available: https://www.taxand.com/our-thinking/news/new-thin-capitalisation-rules/.

[4] Deloitte, “'Indonesia's New Armor - Thin Capitalization Rules." [Online]. Available: https://www2.deloitte.com/content/dam/Deloitte/id/Documents/tax/id-tax-alert-ensep2015-noexp.pdf.

[5] G. Karnik, "Concept of Thin Capitalisation - An Overview." [Online]. Available: https://www.academia.edu/4499122/Concept_of_Thin_Capitalisation_-_An_overview.

[6] F. Cao, "China's Thin Capitalization Rule." [Online]. Available: https://www.jonesday.com/Chinas-Thin-Capitalization-Rule-11-07-2008/\#.

[7] Ricciuti, Roberto, A. Savoia, and K. Sen, "'What Determines Administrative Capacity in Developing Countries?," Int. Tax Public Financ. J., 2019. 